\title{
Studies on the relationship between adhesive activity and haemagglutination by Helicobacter pylori
}

\author{
TAKAKO OSAKI, HIROYUKI YAMAGUCHI*, HARUHIKO TAGUCHI*, JUNKO KUMADA*, \\ SACHIO OGATA* and SHIGERU KAMIYA* \\ Division of Flow Cytometry, * Department of Microbiology, Kyorin University School of Medicine, 6-20-2 \\ Shinkawa, Mitaka, Tokyo 181, Japan
}

\begin{abstract}
The adhesion of Helicobacter pylori to gastric carcinoma cells (MKN45, KatoIII and MKN28) and Intestine-407 cells was tested by flow cytometric analysis. The mean adhesion rates of $\boldsymbol{H}$. pylori strains to MKN45, KatoIII and Intestine-407 cells were 90.5, 42.7 and $15.1 \%$, respectively. There was no statistical correlation between the adhesion rates to MKN45 cells and haemagglutination (HA) activity of $H$. pylori strains, although $H$. pylori strains with high $\mathrm{HA}$ activity with human type $\mathrm{O}$ erythrocytes tended to adhere effectively to MKN45 cells. No correlation between adhesion and production of vacuolating toxin was observed.
\end{abstract}

\section{Introduction}

Helicobacter pylori is a curved spiral gram-negative bacterium that is implicated as a gastroduodenal pathogen in man. It is now recognised as an aetiological agent of chronic active (type B) gastritis and peptic ulcer disease [1-3]. In addition, there is an epidemiological associaton with the incidence of gastric carcinoma $[4,5]$.

There are many reports on the adhesion of $H$. pylori to various cultured epithelial cells by microscopical analysis [6-9]. Flow cytometry with cultured cells was demonstrated to be a sensitive and objective method to evaluate adhesion of $H$. pylori [10-12]. The haemagglutinin of $H$. pylori has been implicated as an adhesin or colonisation factor antigen [13-17].

Several virulence factors of $H$. pylori - urease, flagella, adhesin and vacuolating toxin (VT) - are recognised. Furthermore, a subset of strains also produce VT, which induces cellular vacuolation in a number of different epithelial cell lines in vitro [18$20]$, and VT is thought to be important for virulence of $H$. pylori in a mouse model of disease [21, 22]. Although cytotoxin associated gene product (CagA) has been implicated in the production of cytokines by gastric epithelial cells after $H$. pylori infection, it was reported recently that picAB genes upstream to the

Received 27 Feb. 1996; revised version accepted 13 June 1996. Corresponding author: Dr T. Osaki.
cagA gene are responsible for the production of cytokines by gastric epithelial cells [23].

This study examined adhesion of $H$. pylori to various cultured cells. Moreover, to study strain diversity, the adhesion rate of $H$. pylori strains was compared with their haemagglutination activity (HA) and production of vacuolating toxin (VT).

\section{Materials and methods}

Bacterial strains and growth conditions

H. pylori TK and KR strains were isolated from gastric biopsy samples of patients as described previously [24]. H. pylori NCTC 11638 was kindly provided by Dr T. Itoh (Tokyo Metropolitan Research Laboratory of Public Health). All strains were stored at $-80^{\circ} \mathrm{C}$ until used in this study. For the assay of HA and adhesion, they were cultured on Brain Heart Infusion (BHI) Agar (Difco) containing defibrinated horse blood 5\% (v/v) under micro-aerophilic conditions $\left(\mathrm{O}_{2} 5 \%, \mathrm{CO}_{2} 10 \%\right.$, $\mathrm{N}_{2} 85 \%$ ) for $3-4 \mathrm{~d}$ at $37^{\circ} \mathrm{C}$. These cultures were harvested in Hanks's Balanced Salts Solution (Gibco BRL, Gaithersburg, USA) containing gelatin $0.1 \%$ (HGS).

\section{Cell culture}

Human gastric carcinoma cells, MKN45, MKN28 and KATOIII, were obtained from the Japanese Cancer Research Resources Bank. The human intestinal cell 
line, Intestine (Int)-407 was kindly provided by $\mathrm{Dr}$ Kanamori (Kyorin University). They were grown at $37^{\circ} \mathrm{C}$ in RPMI-1640 or kanamycin-free Eagle's MEM (Gibco) containing fetal calf serum (FCS) $10 \%$, in an atmosphere containing $\mathrm{CO}_{2} 5 \%$. For the adhesion assay, cells were harvested from a flask by scraping with a sterile cell scraper (Falcon, NJ, USA), and centrifugation at $200 \mathrm{~g}$ for $5 \mathrm{~min}$ followed by resuspension in HGS.

\section{Adhesion assay}

Adhesion was assayed by the method of Dunn et al. [8]. The epithelial cells $\left(5 \times 10^{6}\right.$ cells $)$ and $H$. pylori $\left(5 \times 10^{8}-1 \times 10^{9}\right)$ were mixed in a sample tube $(1 \mathrm{ml}$ of HGS) followed by incubation at $37^{\circ} \mathrm{C}$ for $1 \mathrm{~h}$ with gentle shaking. Non-adherent bacteria were removed by centrifugation at $1000 \mathrm{rpm}$ for $10 \mathrm{~min}$ on to $9 \mathrm{ml}$ of sucrose $15 \%$ solution. Cells were washed once with HGS and treated with anti-H. pylori hyper-immune rabbit serum diluted 1 in 1000 with HGS for $30 \mathrm{~min}$ on ice. The cells were washed twice with HGS and stained with fluorescein isothiocyanate (FITC)-conjugated goat anti-rabbit immunoglobulin G (Capel, Durham, USA) diluted 1 in 20 with HGS for $30 \mathrm{~min}$ on ice. The cells were then washed twice with HGS and resuspended in $300 \mu 1$ of PBS for the flow cytometric analysis. The EPICS-CS flow cytometer (Coulter Electronics, Hialeah, USA) was used for the measurement of bacteria adhering to the epithelial cells. The machine was gated to include single cells and to exclude not only cell debris but also non-adherent aggregated bacteria by means of a dot-plot display of forward-angle light scatter (FLS) and 90LS. Fluorescence data were acquired in log mode on a 256-channel scale. The mean fluorescence channel was calculated by an analysis of $>5000$ individual cells. The results were expressed as the percentage of fluorescent cells (positive percent) calculated from the fluorescence frequency distribution histograms. The threshold of cells without adherent bacteria was established for each experiment, which was stained with subsequent twostep FITC-conjugated $H$. pylori antibody staining as described above.

\section{Haemagglutination assay}

The haemagglutination assay was by the method of Kobayashi et al. [6]. H. pylori harvested from BHI agar plates containing horse blood $5 \%$ were washed once and suspended in PBS. Samples $(100 \mu \mathrm{l}) ; c$. $10^{8} \mathrm{cfu} / \mathrm{ml}$ ) of the bacterial suspension to be tested were serially diluted in two-fold steps with $100 \mu$ of PBS in a round-bottomed microtitration plate and $100 \mu \mathrm{l}$ of erythrocytes (bovine, chicken, guinea-pig, horse, human, rabbit and sheep), $1 \%$ suspension in PBS, was added to each well and mixed. The plate was left at room temperature for $3 \mathrm{~h}$. The titre was defined as the highest dilution showing visible haemagglutination.

\section{Vacuolating toxin assay}

Vacuolating toxin titre of culture filtrates of $H$. pylori was determined as described previously [20]. H. pylori was cultured in micro-aerophilic conditions with BHI broth containing FCS $5 \%$ for 6 days. The culture supernate to be tested was collected and was serially diluted in two-fold steps with RPMI-1640. Rabbit kidney (RK-13) cells were treated with the culture filtrates $(50 \mu \mathrm{l})$ of $H$. pylori. After incubation for $24 \mathrm{~h}$ a morphological change of cytoplasmic vacuolation was observed microscopically. The titre was the highest dilution of the filtrate inducing vacuolation of $>10 \%$ of cells.

\section{Results}

\section{Adhesion of $H$. pylori to various cell lines}

Adhesion of $H$. pylori to MKN45, KatoIII, MKN28 and Int-407 cells was tested by flow cytometry. The percentage (adhesion rate) of the fluorescence-positive cells was calculated according to the threshold between control cells which had not been exposed to $H$. pylori and positively stained cells with adherent $H$. pylori. The adhesion rates of $H$. pylori strain NCTC 11638 to MKN45, KatoIII, MKN28 and Int-407 cells were 87, 59, 3 and 14\%, respectively (Fig. 1). During incubation with $H$. pylori strain NCTC 11638 , many MKN28 cells were lysed and the adhesion rate of $H$. pylori was the lowest $(3 \%)$. The mean adhesion rates of $H$. pylori clinical isolates to MKN45, KatoIII and Int-407 were $90.5 \%$ (39 strains tested), $42.7 \%$ (15 strains tested) and $15.1 \%$ (15 strains tested), respectively. The adhesion rate of $H$. pylori to MKN45 cells correlated with that for KATOIII cells $(\mathrm{r}=0.86)$, but not that for Int-407 cells. The adhesion rate of 39 strains of $H$. pylori to MKN45 cells was between 57 and 98\%, and the mean channel number of these histograms was between 132 and 209 (data not shown).

\section{HA activity of $H$. pylori}

Sixty-five strains of $H$. pylori were tested for HA activity with bovine, chicken, guinea-pig, horse, human, rabbit and sheep erythrocytes (Table 1). In the HA test with guinea-pig erythrocytes, it was shown that 63 strains $(97 \%)$ of $H$. pylori were haemagglutinationpositive and the mean titre $\left(2^{5.6}\right)$ was the highest among the erythrocytes of seven species (Table 1). Of $65 \mathrm{H}$. pylori strains, 20 strains showed positive HA with erythrocytes of seven species. In contrast, only two strains showed negative HA with erythrocytes of the seven species tested. Seventeen $H$. pylori strains failed to haemagglutinate horse or bovine erythrocytes. No common characteristic profile in the HA test was demonstrated for the remaining $26 \mathrm{H}$. pylori strains (data not shown). There was no statistical correlation between HA titre and adhesive activity of strains of $H$. pylori. However, when the strains of $H$. pylori showing 


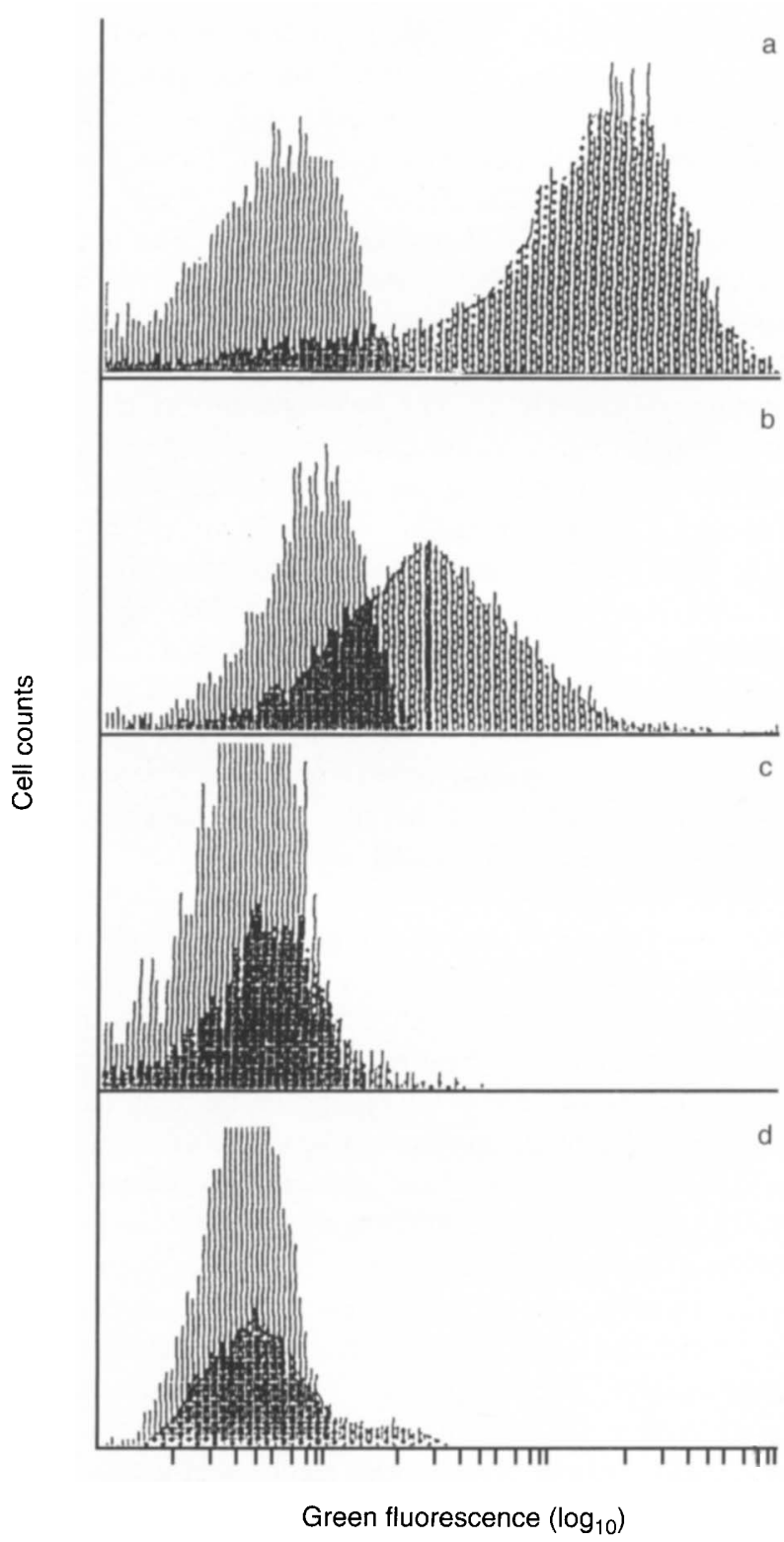

Fig. 1. Flow cytometric analysis of adhesion of $H$. pylori to various cultured cells. a, MKN45; b, KatoIII; c, MKN28; d, Int-407; [II, histogram of control cells; cells after incubation with $H$. pylori.

Table 1. Haemagglutination activity of $H$. pylori strains with erythrocytes of various animal species

\begin{tabular}{lcc}
\hline Erythrocyte & HA positive strains $(\%)^{*}$ & Mean HA titre $\left(\log _{2}\right) \dagger$ \\
\hline Guinea-pig & 97 & 5.6 \\
Rabbit & 95 & 3.6 \\
Human $\ddagger$ & 89 & 3.5 \\
Sheep & 88 & 3.0 \\
Chicken & 63 & 3.8 \\
Horse & 57 & 2.2 \\
Bovine & 57 & 2.5 \\
\hline
\end{tabular}

${ }^{*}$ Sixty-five strains of $H$. pylori were tested for HA.

† Mean HA titre of HA positive strains.

$\ddagger$ ¿lood type $\mathrm{O}$.

high HA activity with human erythrocytes (titre $2^{5-7}$ ) were tested, adhesion to MKN45 cells was more intensive in the flow cytometric analysis with a mean adhesion rate of $92.4 \%$ (Table 2).
Table 2. HA activity and adhesive activity of $H$. pylori strains

\begin{tabular}{lcc}
\hline $\begin{array}{l}\text { HA titre } \\
\left(\log _{2}\right)\end{array}$ & $\begin{array}{c}\text { Number of strains } \\
\text { tested }\end{array}$ & Mean (SD) adhesion rate (\%) \\
\hline $0-1$ & 8 & $78.9(16.6)$ \\
$2-4$ & 21 & $87.9(9.0)$ \\
$5-7$ & 10 & $92.4 \quad(5.6)$ \\
\hline
\end{tabular}

\section{Production of vacuolating toxin (VT)}

Sixty-five strains of $H$. pylori were tested for production of VT; 32 strains $(49 \%)$ were shown to be cytotoxic. There was no statistical correlation between VT titre and adhesion rate to MKN45 cells of $38 \mathrm{H}$. pylori strains (Table 3 ) tested for both. It was also shown that VT titre was not correlated with adhesion rate of $H$. pylori strains when KatoIII cells were used (data not shown).

\section{Discussion}

There have been many reports on the adhesion of $H$. pylori to various epithelial cells determined by microscopy [6-9]. In the present study, adhesion of H. pylori

Table 3. VT production and adhesiveness to MKN45 cells of $H$. pylori strains

\begin{tabular}{|c|c|c|}
\hline $\begin{array}{l}\text { Strain } \\
\text { no. }\end{array}$ & $\begin{array}{l}\text { VT titre } \\
\left(\log _{2}\right)\end{array}$ & $\begin{array}{l}\text { Adhesion } \\
\text { rate }(\%)\end{array}$ \\
\hline TK1301 & 4 & 98.2 \\
\hline TK1308 & 4 & 96.4 \\
\hline TK1029 & 4 & 93.6 \\
\hline TK1076 & 3 & 97.4 \\
\hline TK1023 & 3 & 93.7 \\
\hline TK1302 & 2 & 98.4 \\
\hline TK1307 & 2 & 95.3 \\
\hline TK1135 & 2 & 94.1 \\
\hline TK1021 & 2 & 77.4 \\
\hline TK1057 & 2 & 68.6 \\
\hline TK1078 & 1 & 98.1 \\
\hline TK1313 & 1 & 97.7 \\
\hline KR2072 & 1 & 97.3 \\
\hline TK1147 & 1 & 96.8 \\
\hline TK1054 & 1 & 95.6 \\
\hline TK1042 & 1 & 95.5 \\
\hline KR2048 & 1 & 94.1 \\
\hline TK1102 & 1 & 93.7 \\
\hline TK1103 & 1 & 83.8 \\
\hline TK2070 & 0 & 96.3 \\
\hline TK1309 & 0 & 90.3 \\
\hline TK1063 & - & 97.6 \\
\hline TK1064 & - & 97.5 \\
\hline TK1030 & - & 95.5 \\
\hline TK1311 & - & 95.4 \\
\hline TK1003 & - & 94.9 \\
\hline TK1310 & - & 92.9 \\
\hline TK1028 & - & 91.1 \\
\hline NCTC11638 & - & 87.2 \\
\hline TK1025 & - & 86.6 \\
\hline TK1104 & - & 84.6 \\
\hline TK1008 & - & 84.4 \\
\hline TK1046 & - & 83.9 \\
\hline TK1079 & - & 74.8 \\
\hline TK1045 & - & 73.0 \\
\hline TK1022 & - & 65.4 \\
\hline TK1126 & - & 60.0 \\
\hline TK1036 & - & 57.4 \\
\hline
\end{tabular}


to various gastric and intestinal epithelial cells was analysed by flow cytometry. The cells incubated with H. pylori were more intensively stained than control cells not incubated with bacteria. The mean adhesion rates of the tested strains of $H$. pylori to MKN45, KatoIII and Int-407 were 90.5, 42.7 and $15.1 \%$, respectively. These results indicate that the MKN45 cell line is the most sensitive for adhesion of $H$. pylori. It was also shown by microscopy that many more bacteria attached to the cell surface of MKN45 than to other cells.

Many studies evaluating $H$. pylori adhesion in vitro have shown binding of the bacteria to various tissue culture cell lines, including KatoIII $[10,11,25,26]$, HEp-2 [26, 27] and Int-407 [28]. It has been reported that KatoIII is an ideal cell line for flow cytometric analysis as the cells grow in suspension and can be removed from the surface of the flask without the use of trypsin $[10,11]$. Similarly, MKN45 cells grow both in suspension and on the surface of the flask, and it is not necessary to use proteolytic enzyme to remove the cells. Interestingly, a significant correlation was observed between the adhesion rates of $H$. pylori to MKN45 and to KatollI, suggesting that a receptor for $H$. pylori on the cell surface of MKN45 was similar to that on KatollI. Adhesion of H. pylori to MKN28 was not evaluable under the conditions used, because of cell lysis, indicating that MKN28 was not a suitable cell line for the adhesion assay by flow cytometry. The mechanism by which $H$. pylori adheres to various human gastric carcinoma cells with a different affinity is not clear. MKN45, KatoIII and MKN28 cell lines originated from poorly differentiated adenocarcinoma, signet cell carcinoma and well-differentiated tubular adenocarcinoma, respectively [29, 30]. Therefore, it is possible that the affinity of $H$. pylori to gastric carcinoma cells in terms of adhesion might be due to different surface structures based upon its tumour characteristics.

The adhesion rate of $H$. pylori to Int-407 was relatively low in comparison to MKN45 and KatoIII cells, suggesting that $H$. pylori has an affinity for gastric cells rather than intestinal cells. It is well known that $H$. pylori colonises the gastric epithelial cell surface and gastric metaplasia in the duodenum [31-34]. It was also reported that binding of Helicobacter spp. was greater to lipids derived from ferret antrum compared to colon in a solid-phase binding assay based on thin-layer chromatography [27].

Several investigators have confirmed the expression of HA by $H$. pylori $[6,11,13-15]$. Robinson et al. [15] reported a grouping of $H$. pylori strains according to erythrocyte HA of various animals. In their report, all except one of 14 strains showed HA with erythrocytes of guinea-pigs, man and sheep. Three groups were separated according to HA with chicken, bovine and horse erythrocytes. Group 1 strains aggregate with chicken and bovine erythrocytes, but not with those of horse. Group 2a strains caused HA with chicken erythrocytes, but not with bovine or horse erythrocytes, and Group $2 b$ strains were HA negative with chicken, bovine and horse erythrocytes. Similarly, in the present study, HA was less between $H$. pylori strains and chicken, horse and bovine erythrocytes than with guinea-pig, rabbit, human and sheep erythrocytes (Table 1). The heterogeneity of $H$. pylori strains with regard to the expression and specificity of surface haemagglutinins was demonstrated. It has been reported that among different species of erythrocyte, the sialic acid content is high in guinea-pig and human, but low in horse erythrocytes [35, 36]. Also, sialic acid as $\mathrm{N}$-acetyl neuraminic acid is dominant in human erythrocytes, but sialic acid as an N-glycoslyl derivative is dominant in horse erythrocytes [36]. The difference in the positivity of HA with erythrocytes of different species might be due to the quantity and quality of sialic acid located on erythrocytes.

HA by $H$. pylori was reported to be inhibited by pre-treatment of $H$. pylori with fetuin, a glycoprotein rich in sialylated oligosaccharides $[11,13,15]$. Furthermore, neuraminidase treatment of erythrocytes resulted in inhibition of $\mathrm{HA}[11,13]$, indicating that the HA receptor on the erythrocytes contains sialylated oligosaccharides. We have reported previously that there is no significant inhibition in the adhesion rates of $H$. pylori to MKN45 cells by treatment with fetuin [12], in spite of the finding that HA was completely inhibited by fetuin. Other surface components on $H$. pylori have been reported to be associated with binding to cells. Chimiela et al. [37,38] showed that $H$. pylori strains expressing sialic acid-independent haemagglutinin effectively attached to and were ingested by human polymorphonuclear leucocytes (PMNL), and that $H$. pylori strains expressing sialic acid-specific haemagglutinin effectively attached to, and were ingested by, human PMNL. It was also reported that sulphated glycosaminoglycans such as heparan sulphate bind to $H$. pylori with high affinity [39], suggesting the presence of heparan sulphate binding protein on the surface of $H$. pylori.

In this study, it was observed that the HA titre of $H$. pylori was not significantly correlated with adhesiveness to MKN45 cells, although the strains showing a high titre of HA tended to adhere to MKN45 cells with a high efficiency. These results suggest the possibility that the haemagglutinin and other surface components may be co-operatively involved in adhesion of $H$. pylori to cultured cells.

Among the virulence factors of $H$. pylori, VT appears to be important for the persistence of $H$. pylori and the occurrence of gastroduodenal diseases. It has been reported that gastric disease in an animal model was induced only by infection with VT-producing $H$. pylori 
$[21,22]$. Although this study showed that the ability of $H$. pylori to produce toxin was not correlated with adhesion to MKN45 cells, the direct effect of VT on the adhesion to MKN45 cells needs to be examined in detail.

\section{References}

1. Marshall BJ, Warren JR. Unidentified curved bacilli in the stomach of patients with gastritis and peptic ulceration. Lancet 1984; 1: 1311-1315.

2. Wyatt JI, Dixon MF. Chronic gastritis - a pathogenetic approach. J Pathol 1988; 154: 113-124.

3. Graham DY. Campylobacter pylori and peptic ulcer disease. Gastroenterology 1989; 96: 615-625.

4. Nomura A, Stemmermann GN, Chyou P-H, Kato I, PerezPerez GI, Blaser MJ. Helicobacter pylori infection and gastric carcinoma among Japanese Americans in Hawaii. $N$ Engl $J$ Med 1991; 325: 1132-1136.

5. Parsonnet J, Vandersteen D, Goates J, Sibley, RK, Pritikin J, Chang Y. Helicobacter pylori infection in intestinal- and diffuse-type gastric adenocarcinomas. $J$ Natl Cancer Inst 1991; 83: 640-643.

6. Kobayashi Y, Okazaki K-I, Murakami K. Adhesion of Helicobacter pylori to gastric epithelial cells in primary cultures obtained from stomachs of various animals. Infect Immun 1993; 61: 4058-4063.

7. Evans DG, Evans DJ. Graham DY. Receptor-mediated adherence of Campylobacter pylori to mouse Y-1 adrenal cell monolayers. Infect Immun 1989; 57: 2272-2278.

8. Fauchère JL, Blaser MJ. Adherence of Helicobacter pylori cells and their surface components to HeLa cell membranes. Microb Pathog 1990; 9: 427-439.

9. Falk P, Roth KA, Borén T, Westblom TU, Gordon JI, Normark S. An in vitro adherence assay reveals that Helicobacter pylori exhibits cell lineage-specific tropism in the human gastric epithelium. Proc Natl Acad Sci USA 1993; 90: $2035-2039$.

10. Dunn BE, Altmann M, Campbell GP. Adherence of Helicobacter pylori to gastric carcinoma cells: analysis by flow cytometry. Rev Infect Dis 1991; 13 Suppl 8: S657-S664.

11. Clyne M, Drumm B. Adherence of Helicobacter pylori to primary human gastrointestinal cells. Infect Immun 1993; 61: 4051-4057.

12. Yamamoto-Osaki $\mathrm{T}$, Yamaguchi $\mathrm{H}$, Taguchi $\mathrm{H}$, Ogata $\mathrm{S}$, Kamiya S. Adherence of Helicobacter pylori to cultured human gastric carcinoma cells. Eur $J$ Gastroenterol Hepatol 1995; 7 Suppl 1: S89-S92.

13. Evans DG, Evans DJ, Moulds JJ, Graham DY. N-acetylneuraminyllactose-binding fibrillar hemagglutinin of Campylobactor pylori: a putative colonization factor antigen. Infect Immun 1988; 56: 2896-2906.

14. Nakazawa T, Ishibashi M, Konishi H, Takemoto T, Shingeeda M, Kochiyama T. Hemagglutination activity of Campylobactor pylori. Infect Immun 1989; 57: 989-991.

15. Robinson J, Goodwin CS, Cooper M, Burke V, Mee BJ. Soluble and cell-associated haemagglutinins of Helicobacter (Campylobacter) pylori. J Med Microbiol 1990; 33: 277-284.

16. Huaung J, Keeling PWN, Smyth CJ. Identification of erythrocyte-binding antigens in Helicobactor pylori. $J$ Gen Microbiol 1992; 138: 1503-1513.

17. Emödy L, Carlsson $\AA$, Ljungh Å, Wadström T. Mannoseresistant haemagglutination by Campylobacter pylori. Scand $J$ Infect Dis 1988; 20: 353-354.

18. Leunk RD, Johnson PT, David BC, Kraft WG, Morgan DR. Cytotoxic activity in broth-culture filtrates of Campylobacter pylori. J Med Microbiol 1988; 26: 93-99.
19. Cover TL, Blaser MJ. Purification and characterization of the vacuolating toxin from Helicobacter pylori. J Biol Chem 1992; 267: 10570-10575.

20. Kamiya S, Kai M, Ozawa A et al. Characteristics of vacuolating toxin produced by Helicobacter pylori. Eur $J$ Gastroenterol Hepatol 1994; 6 Suppl 1: S23-S27.

21. Marchetti M, Aricò B, Burroni D, Figura N, Rappuoli R, Ghiara P. Development of a mouse model of Helicobacter pylori infection that mimics human disease. Science; $\mathbf{2 6 7}$ $1655-1658$

22. Ghiara P, Marchetti M, Blaser MJ et al. Role of the Helicobacter pylori virulence factors vacuolating cytotoxin, $\mathrm{CagA}$, and urease in a mouse model of disease. Infect Immun 1995; 63: 4154-4160.

23. Tummuru MKR, Sharma SA, Blaser MJ. Helicobacter pylori picB, a homologue of the Bordetella pertussis toxin secretion protein, is required for induction of IL-8 in gastric epithelial cells. Mol Microbiol 1995; 18: 867-876.

24. Kamiya S, Taniguchi I, Yamamoto $\mathrm{T}$ et al. Evaluation of rapid urease test for detection of Helicobacter pylori in gastric biopsy specimens. Eur J Epidemiol 1993; 9: 450-452.

25. Hemalatha SG, Drumm B, Sherman P. Adherence of Helicobacter pylori to human gastric epithelial cells in vitro. J Med Microbiol 1991; 35: 197-202.

26. Dytoc M, Gold B, Louie M et al. Comparison of Helicobactor pylori and attaching-effacing Escherichia coli adhesion to eukaryotic cells. Infect Immun 1993; 61: 448-456.

27. Gold BD, Dytoc M, Huesca $\mathrm{M}$ et al. Comparison of Helicobacter mustelae and Helicobacter pylori adhesion to eukaryotic cells in vitro. Gastroenterology 1995; 109: 692-700.

28. Neman-Simha V, Mégraud F. In vitro model for Campylobacter pylori adherence properties. Infect Immun 1988; 56: 3329-3333.

29. Sekiguchi M, Sakakibara K, Fujii G. Establishment of cultured cell lines derived from a human gastric carcinoma. Jpn J Exp Med 1978; 48: 61-68.

30. Motoyama T, Hojo H, Watanabe H. Comparison of seven cell lines derived from human gastric carcinomas. Acta Pathol Jpn 1986; 36: 65-83.

31. Hazell SL, Hennessy WB, Borody TJ et al. Campylobacter pyloridis gastritis. II. Distribution of bacteria and associated inflammation in the gastroduodenal environment. $A m J$ Gastroenterol 1987; 82: 297-301.

32. McNulty CAM, Watson DM. Spiral bacteria of the gastric antrum. Lancet 1984; 1: 1068-1069.

33. Offerhaus GJA, Molyvas EN, Hoedemaeker PJ. Helicobacter pylori infection of gastric mucin cell metaplasia: the duodenum revisited. J Pathol 1990; 162: 239-243.

34. Steer HW. Surface morphology of the gastroduodenal mucosa in duodenal ulceration. Gut 1984; 25: 1203-1210.

35. Eylar EH, Madoff MA, Brody OV, Oncley JL. The contribution of sialic acid to the surface charge of the erythrocyte. J Biol Chem 1962; 237: 1992-2000.

36. Angel MA, Burness ATH. The attachment of encephalomyocarditis virus to erytthrocytes from several animal species. Virology 1977; 83: 428-432.

37. Chmiela M, Lelwala-Guruge J, Wadström $\mathrm{T}$. Interaction of cells of Helicobacter pylori with human polymorphonuclear leucocytes: possible role of haemagglutinins. FEMS Immunol Med Microbiol 1994; 9: 41-48.

38. Chmiela M, Paziak-Domanska, Wadström T. Attachment, ingestion anf intracellular killing of Helicobacter pylori by human peripheral blood mononuclear leukocytes and mouse peritoneal inflammatory macrophages. FEMS Immunol Med Microbiol 1995; 10: 307-316.

39. Hirmo $S$, Utt $M$, Ringner $M$, Wadström $T$. Inhibition of heparan sulphate and other glycosaminoglycans binding to Helicobacter pylori by various polysulphated carbohydrates. FEMS Immunol Med Microbiol 1995; 10: 301-306. 